\title{
Earth architecture: ancient and new methods for durability improvement
}

\author{
R. Eires, A. Camões \& S. Jalali \\ University of Minho, Guimarães, Portugal
}

\begin{abstract}
Quite a big part of the country and world's heritage was made using unfired earth constructions. The new earth buildings, as well as the conservation of the existent heritage, need scientific knowledge to allow higher durability. This durability is particularly conditioned by erosion caused by water action, especially in countries with high rainfall index. Analyzing the old building techniques, that allow protection on the earth material from water action, it is possible to understand how many earth buildings were preserved, during several centuries, resisting to harsh weather conditions. Among these techniques there are specially the incorporation of biopolymers (such as oils or fats), the addition of some minerals and stabilization with lime. However, this knowledge seems to have been forgotten. The authors study new methods of soil stabilization, with lime and biopolymers, adapting the ancient knowledge to improve the durability, specially related to the water action.
\end{abstract}

\section{INTRODUCTION}

After the decade of 1950, and mainly in the last years, the interest of earth architecture reemerges concerning the actual environmental issues in the world. This way, new technologies appear to improve the durability of earth architecture.

New processes were developed to make earth pressed blocks and monolithic walls with earth using machines for static or dynamic press, as well as extrusion processes to make blocks or plates and sprayed processes to apply earth mixtures directly in situ.

In the last years studies of soil stabilization using natural or synthetic additives have been also performed by some researchers in order to evaluate the durability performance of earth as a construction material. These studies about soil stabilization methods show that, with the incorporation of appropriate stabilizing agents, it is possible to obtain earth architecture with greater durability against water actions. This increase of earth building durability could help to change the inappropriate and prejudiced perception still existing about the earth material.

This paper presents also an experimental research work carried out by the author Rute Eires during her $\mathrm{PhD}$ thesis (Eires, 2012) with supervise of the other authors. One part of this research deals about techniques of protection against water action for earth construction and is presented here, as well as the main tests and results obtained on the experimental work. The motivation for this research was the lack of knowledge about methods to improve the durability of earth material and the necessity of more scientific research about soil stabilization specifically to get a better performance against water action. This way, the main objective was to achieve soil stabilization mixtures for building with compressed earth (rammed earth or compressed earth blocks, CEB) without additional coating, obtaining a good durability against water without compromise the aesthetic potential of the earth material. 


\section{ANCIENT AND NEW METHODS OF SOILS STABILIZATION}

In ancient times, in order to protect earth buildings from the action of rain and water absorption, different construction techniques were used. The soils stabilization was also a way to raise the durability of earth buildings by the increasing of their mechanical strength and resistance against water action. Like that, since ancient times, different stabilizers and additives has been mixed to earth material. Next, one will present three common materials that can be used for this purpose individually or combined with each other.

\subsection{Stabilization with lime and pozzolans}

Pozzolan is a high fineness material that, when added to lime, becomes cementitious in the presence of water. This property can be beneficial in soil stabilization and in mortars or plasters with lime to coat the earth walls. There is a millennial example of lime-pozzolana utilization in earth constructions and mortars, the "sarooj". This material has origin in Iran and it has been used to protect earth buildings from water action. The "sarooj" is a binding durable material and it consists in a pozzolanic mixture based on clayey soil (sand and clay), lime, ashes and other additives. This mixture results in a material similar to hydraulic portland cement. It was applied for water thanks typical from Iran, called " $\bar{a} b a n b \bar{a} r$ ", as in ice Iranian reservoirs called "Yakhchal" (Hutton 2010 and Malekzadeh 2007).

Research works realized by the authors at University of Minho reveal that the soil stabilization with a mixture of metakaolin/lime (5\% of soil mass) increases the compressive strength comparing to the unstabilized ones (Eires at al, 2009).

\subsection{Stabilization with biopolymers and lime}

Polymers can be from natural or artificial source and from biological (vegetable or animal) or mineral origin. At the present text the mentioned biopolymers are organic ones from natural and biological origin, without any kind of laboratorial synthesizing.

The major influence of biopolymers addition in earth construction is the result of rheological effects developed in clay particles of soil. The main verified action is related with the biopolymers capability to change the electrostatic charge of the clay particles. This effect causes dispersion and posterior attraction, that change the particles from a state of face to face (Fig. 1 - a) to a state of face to edge (Fig. 1 - b).

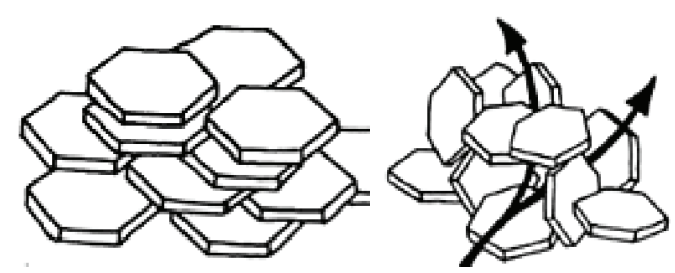

Figure 1. Clay boards: a - face to face and b - face to edge (Hamer et al 1975)

The incorporation of biopolymers on earth construction was carried out for a long time and they were particularly used in order to improve the behaviour against water. There are numerous examples of biopolymers that have been added as stabilizers in earth construction, some from vegetable origin, such as flours, starches, gums, cactus, oils, waxes or resins of plants and others from animal origin, such as animal fats, whey, casein, egg whites, blood, excrement and urine (Eires et al, 2010).

At table 1 one can see some examples of ancient techniques with biopolymers addiction in soil stabilization or in mortars or paints preparation for protection of earth construction from rain effects. For each technique, in addition to resistance to the water action, one presents other properties that will have influence on the durability of the material.

At table 2 one presents contemporaneous research works that used biopolymers addiction to improve the durability of soil. Some authors mention in particular an improvement of performance against water action, both at accelerated erosion or water absorption. 
Table 1. Biopolymers at ancient earth construction

\begin{tabular}{|c|c|c|}
\hline Local/Reference & Biopolymer (s) & Techniques / properties \\
\hline India & \multirow[t]{2}{*}{ Cow dung or urine } & "Gohber" - plaster technique with cow dung \\
\hline BASIN et al 2002 & & Horse urine - acts as a hardener \\
\hline North of Gana & \multirow{2}{*}{-Dung and carob tree pods } & Paint - hardener of walls and floors in lat- \\
\hline Beas 1991 & & eritic soils. \\
\hline Egypt and Sudan & \multirow{2}{*}{$\begin{array}{l}\text { Straw and dung with fer- } \\
\text { mentation }\end{array}$} & \multirow[t]{2}{*}{ Adobes and plasters - enhanced resistance. } \\
\hline Hassan Fathy 1969 & & \\
\hline México and pre-Columbian people & \multirow{2}{*}{$\begin{array}{l}\text { Nopal - catus } \\
\text { Nopalea coccinellifera }\end{array}$} & \multirow{2}{*}{$\begin{array}{l}\text { Used in manufacture of lime based paints to } \\
\text { allow the addition of other decorations mate- } \\
\text { rials in earth walls. }\end{array}$} \\
\hline $\begin{array}{l}\text { CPNT - Consejo de Promocion de } \\
\text { Nopal y Tuna } 2009\end{array}$ & & \\
\hline México and EUA southwest & \multirow{2}{*}{$\begin{array}{l}\text { Agave - catus Leuchten- } \\
\text { bergia principis }\end{array}$} & \multirow{2}{*}{$\begin{array}{l}\text { Used in mortars - boiled and kept for two or } \\
\text { three weeks before to mix in the clay mortar. }\end{array}$} \\
\hline Beas 1991 & & \\
\hline South America, specially Peru & \multirow{2}{*}{$\begin{array}{l}\text { Tuna - catus } \\
\text { Opuntia Ficus Indica }\end{array}$} & \multirow[t]{2}{*}{ Soil stabilizer for walls and plasters. } \\
\hline Beas 1991 & & \\
\hline South America and Africa & \multirow{2}{*}{$\begin{array}{l}\text { Látex - natural resin } \\
\text { Hevea Euphorbiacex }\end{array}$} & \multirow[t]{2}{*}{ Paints } \\
\hline Beas 1991 & & \\
\hline South America and Africa & \multirow{2}{*}{$\begin{array}{l}\text { Banana - stems and } \\
\text { leaves }\end{array}$} & \multirow{2}{*}{$\begin{array}{l}\text { Boiled for mortars and paints (only leaves). } \\
\text { The fibres avoid the cracks. }\end{array}$} \\
\hline Beas 1991 & & \\
\hline Malaya, Indonesia and India Este & \multirow{2}{*}{$\begin{array}{l}\text { Dammar - natural resin } \\
\text { Diopterocarpaceae }\end{array}$} & \multirow[t]{2}{*}{ Mortars } \\
\hline Beas 1991 & & \\
\hline "Asia minor" & \multirow[b]{2}{*}{ Animal blood } & \multirow{2}{*}{$\begin{array}{l}\text { Used in oil or mortars with or without lime. } \\
\text { Present a high risk of fungi growth. } \\
\text { Technique that fell into disuse. }\end{array}$} \\
\hline Winkler, 1956, in Beas 1991 & & \\
\hline "Babylonia" (century V b.C.) & \multirow{2}{*}{ - Natural bitumen } & \multirow{2}{*}{$\begin{array}{l}\text { Resultant from natural decomposition of } \\
\text { vegetable or animals. Soil stabilizer. More } \\
\text { effective in soils with little clay. }\end{array}$} \\
\hline Maniatidis et al 2003 & & \\
\hline Portugal & \multirow[t]{2}{*}{ Animal tallow } & \multirow{2}{*}{$\begin{array}{l}\text { Used with lime as soil stabilizer for walls } \\
\text { and plasters. }\end{array}$} \\
\hline (CML, 2005) & & \\
\hline
\end{tabular}

Table 2. Biopolymers at contemporaneous earth construction

\begin{tabular}{|c|c|c|}
\hline Reference & Biopolymer (s) & Techniques / properties \\
\hline Minke, 2007 & \multirow{3}{*}{ Linseed oil } & $\begin{array}{l}\text { Addition of } 6 \% \text { boiled oil in earth mortars. Accelerated } \\
\text { erosion tests by water jet - without erosion after } 7 \text { days. }\end{array}$ \\
\hline Čechová, 2009 & & $\begin{array}{l}\text { Lime mortars with } 1 \text { and } 3 \% \text { oil (weight of lime). Good } \\
\text { results in water absorption. }\end{array}$ \\
\hline $\begin{array}{l}\text { Santiago \& Mendonca, } \\
\text { 1992, in Čechová, } 2009\end{array}$ & & $\begin{array}{l}\text { Lime mortars with } 2 \text { and } 5 \% \text { of oil (weight of lime). } \\
\text { Good results in water absorption. }\end{array}$ \\
\hline Minke, 2006 & $\begin{array}{l}\text { Linseed oil, } \\
\text { starch, cellulose } \\
\text { and whey }\end{array}$ & $\begin{array}{l}\text { Soil stabilization with: } 3 \% \text { linseed oil, } 1 \text { and } 2 \% \text { starch, } \\
0,5 \text { and } 0,75 \% \text { cellulose; and } 2 \text { and } 4 \% \text { whey, in sandy } \\
\text { soil. Better resistances with linseed oil. }\end{array}$ \\
\hline Kamang, 1998 & Earthworm cast & $\begin{array}{l}\text { CEB with a biological waste from Earthworms in pow- } \\
\text { der. (Replacing 2, 4, 6, 8, } 10 \text { and } 12 \% \text { of soil). Good re- } \\
\text { sults with erosion tests by abrasion. The resistance in- } \\
\text { crease until the } 8 \% \text { material added. }\end{array}$ \\
\hline Silva et al, 2010 & $\begin{array}{l}\text { Glucose of } \\
\text { swallows nest }\end{array}$ & $\begin{array}{l}\text { Compound produced by house swallow to build nests } \\
\text { with clay. Laboratory research of this compound in clay } \\
\text { soil. The results reveal increased mechanical properties. }\end{array}$ \\
\hline $\begin{array}{l}\text { Dosier, } \\
\text { in LaBarre, } 2010\end{array}$ & $\begin{array}{l}\text { Bacteria and } \\
\text { urea }\end{array}$ & $\begin{array}{l}\text { Developing of brick with sand stabilized with bacteria, } \\
\text { calcium chloride and urea. The result material seems like } \\
\text { limestone with resistances as a ceramic brick. }\end{array}$ \\
\hline $\begin{array}{l}\text { Martínez-Camacho et al, } \\
2008\end{array}$ & Nopal-cato & $\begin{array}{l}\text { Rehabilitation of ancient adobe walls in an old building } \\
\text { by painting with nopal. This promotes the chemical in- } \\
\text { teraction with adobe with a consolidate effect. }\end{array}$ \\
\hline
\end{tabular}


Table 2. Biopolymers at contemporaneous earth construction (continuation)

\begin{tabular}{|c|c|c|}
\hline Reference & Biopolymer (s) & Techniques / properties \\
\hline Achenza \& Fenu, 2006 & $\begin{array}{l}\text { Seaweeds fibers } \\
\text { and residues of } \\
\text { beetroot and } \\
\text { tomatoes }\end{array}$ & $\begin{array}{l}\text { Study of stabilized adobe, } 10 \% \text { of soil in fibers and } 10 \% \\
\text { in residues of beetroot and tomatoes. } \\
\text { The results show that the specimens tested are more re- } \\
\text { sistant to immersion in water. }\end{array}$ \\
\hline $\begin{array}{l}\text { Auroville Earth Institute, } \\
2008\end{array}$ & $\begin{array}{l}\text { Tannin- } \\
\text { substance of } \\
\text { vegetable origin }\end{array}$ & $\begin{array}{l}\text { Study of earth mortars for waterproofing roofs with soil, } \\
\text { sand, cement, lime, tannin and alums. The results show } \\
\text { an excellent waterproofing, but only for about } 5 \text { years. }\end{array}$ \\
\hline Browne, 2009 & $\begin{array}{l}\text { Cooking oil, } \\
\text { used engine oil, } \\
\text { animal fat and } \\
\text { goat hair }\end{array}$ & $\begin{array}{l}\text { CEB study of stabilized soil with lime or cement and } \\
\text { with various surface treatments with these biopolymers. } \\
\text { By the fall of water drop "Geelong test", the results show } \\
\text { improvements with the treatment of any of biopolymers } \\
\text { tested, mainly with motor oil and animal fat. }\end{array}$ \\
\hline
\end{tabular}

The use of oils or fats has been the most used waterproof process in earth buildings. These materials were incorporated in the quicklime hydration and there were two different methods in their preparation. It could be by simple hydration, joining oils or fats to the lime with the adequate amount of water and after adding this mixture to the soil or it could be used a process called "hot hydration", mixing simultaneous the soil or clayey sand with oils and fats with the respectively necessary water.

In historical terms, the lime hydration with oils was already cited by Vitruvius, that mentioned about earthen tubes for water, the following "The joints are then to be coated with a mixture of quick lime and oil" (Vitruvius, I century b.C.). At century XVI, it was used as hydrophobic additive a reuse of whale oil that was first used in illumination. This oil with lime formed a material called "gala-gala", commonly used in Açores and Brasil (Veiga 2008). In Portugal, the quick-lime hot hydrated with oils or fats was also used to stabilize earth walls. This kind of use was mentioned for traditional buildings with wood and rammed earth construction in Lisbon (CML, 2005).

In basic surrounding environments, e.g., in earth based plasters with lime or in soil stabilized with lime, if oils or fats are added their triacylglycerols content when hydrated result in insoluble calcium salts of fatty acids. These salts are hydrophobic and connect well with the calcium of lime and provide water repellence (Čechová 2009). The oils and fats usually have a good performance in the capillary absorption, but in other properties such as mechanical strength can cause a decrease in the resistances. In addition, the mechanisms that take place in the microstructure are not clearly known (Čechová 2009). This reduction in resistance is justified by the peculiarity of the oil or fat to encapsulate the calcium hydroxide particles and avoid the carbonation process (Santiago et al, 1992, in Čechová 2009). However, the use of an adequate oil percentage can conduce to superior resistances due to a porosity reduction in the hardened state (Rovnaníková, 2002, in Čechová 2009).

\subsection{Stabilization with mineral additives}

In addition to the known stabilizers such as lime, cement, pozzolans or gypsum, others mineral additions have been used to improve soil characteristics, mainly its durability. Between these additions are some salts and mineral compounds. The most used ones in earth construction are sodium chloride and sodium hydroxide (Houben et al 1989 and Anger et al 2009).

The known effect of sodium chloride is the viscosity control of clay and its consolidation by flocculation of clay particles, binding them again by attraction, depending on the amount of salt contained or added to the soil. This viscosity control is important, once that has influence on the mechanical properties. Consequently, one can reduce the water content and soil porosity, obtaining a more resistant soil mixture (Anger et al 2009).

In Egypt there is an example of a constructive technique little known, used in the building of a 12th century fortress, and other buildings, in the oasis of Siwa that nowadays is still used. This is a masonry performed with blocks of mud rich in salt, linked with mud mortar very rich in salt. The results obtained in tests with this masonry technique show an increase of the mechanical 
properties, although deterioration had been observed with the action of heavy rainfall (Fratini et al, 2009).

The sodium hydroxide, as well as other soda based additives, is known as increasing soil reactivity, developing binder reactions. This can complement the soil stabilization, improving its resistances (Houben et al 1989).

Also the alum is used by it waterproof effect, increased workability and hardening of surfaces (Beas, 1991) see the example in table 2 of Auroville Earth Institute, 2008.

\section{EXPERIMENTAL RESEARCH STUDY}

In the experimental research work one was tested different biopolymers and additives for soil stabilization, as well as the addition of common stabilizers, like lime and cement. The mentioned processes of lime hydration with oils were also studied. Here one will present the main results obtained with the cited ancient technique of hot lime hydration with oils and with the addition of sodium hydroxide as a mineral additive.

\subsection{Methodology, mixtures and tests}

In order to perform the laboratorial tests compressed specimens were prepared in order to simulate CEB or rammed earth. Three different specimens were performed; cylinders of $\varnothing 5 \mathrm{~cm} / 6 \mathrm{~cm}$ of height (made with $2 \mathrm{MPa}$ of pressure that is representative of a CEB manual machine); cylinders of $\varnothing 15 \mathrm{~cm} / 3 \mathrm{~cm}$ of height and cubes of $20 \times 20 \times 20 \mathrm{~cm}^{3}$ (compacted with a pneumatic hammer in order to simulate rammed earth technique).

One was used a soil containing in its composition a little amount of clay, more representative of a poor soil that need a stabilizer to improve its resistances. The soil contains, in mass, $85 \%$ of sand, $6 \%$ of silt and $9 \%$ of clay. Concerning the clay type, it was observed that the soil contain a bigger amount of kaolinite and less illite and montmorillonite.

The used stabilizers were quicklime as the main one, as well as hydrated lime and cement in order to compare the obtained results. Portuguese limes were used, the quicklime (QL) containing in its composition $99 \%$ of $\mathrm{CaO}$ and the hydrated lime (HL) containing $90 \%$ of $\mathrm{CaO}$. The selected cement (C) was the most common used in Portugal - CEM II/B-L 32.5N. In table 2 one can observe the tested mixtures compositions expressed in percentage of mass of soil.

Table 3. Tested mixtures

\begin{tabular}{|c|c|c|c|}
\hline Mixture & Stabilizer & Additive & Biopolymers \\
\hline$\overline{\mathrm{REF}}$ & - & - & - \\
\hline$\overline{\mathrm{C}}$ & Cement $4 \%$ & - & - \\
\hline $\mathrm{HL}$ & Hydrated lime $4 \%$ & - & - \\
\hline $\mathrm{QL}$ & Quicklime 4\% & - & - \\
\hline QL_NaOH & & $\mathrm{NaOH} 0.1 \%$ & - \\
\hline QL_Oil & & - & Oil $1 \%$ \\
\hline QL_Oil_NaOH & & $\mathrm{NaOH} 0.1 \%$ & Oil $1 \%$ \\
\hline
\end{tabular}

The main tests that were performed in this research were: compressive strength in dry and saturated specimens; water absorption by capillarity; accelerated erosion by water jet spray (to simulate the water rain action); and water vapour permeability test. The compressive strength tests were performed in a simple uniaxial testing machine with a displacement velocity of 1 $\mathrm{mm} / \mathrm{min}$ according to ASTM D1633, using cylindrical specimens of $\varnothing 5 \mathrm{~cm} / 6 \mathrm{~cm}$ of height. To obtain the water absorption by capillarity one was based on a method from LNEC (Gomes e Folque 1953), that consist in placing the specimens in a layer of wet sand (using $\varnothing 5 \mathrm{~cm} / 6 \mathrm{~cm}$ cylindrical specimens). The water vapour permeability tests were performed based on EN 1015 19:2000 using cylindrical specimens of $\varnothing 15 \mathrm{~cm} / 3 \mathrm{~cm}$ of height. The accelerated erosion tests by water jet spray were performed based on an Australian standard (Walker 2002), using a jet spray to simulate the rain action. This test with 90 minutes duration simulates about 87 years of rain in Minho, the rainier Portuguese region corresponding to $3000 \mathrm{~mm}$ by year (IM 2005). Figure 2 
shows a graphic scheme of the test and one specimen during the test. The erosion was measured through the depth of cavities, excavated by the water spray jet, in several points, considering an average value.

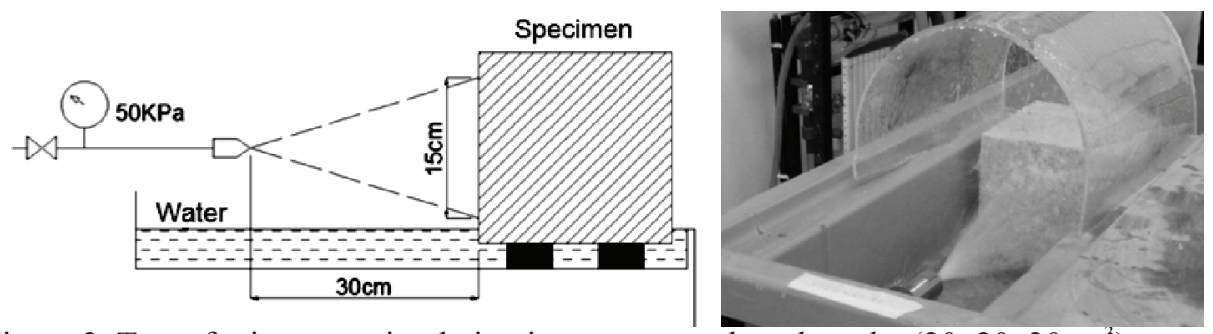

Figure 2. Test of rain water simulation in a compacted earth probe $\left(20 \times 20 \times 20 \mathrm{~cm}^{3}\right)$

\subsection{Obtained results}

The results $(\mathrm{kPa})$ obtained in the compressive strength tests (Fig. 3), considering dry and saturated probes, show that quicklime $(\mathrm{QL})$ provide better resistances than the other stabilizers (HL and $\mathrm{C}$ ). The results also show some advantage due to sodium hydroxide or used oil incorporation.

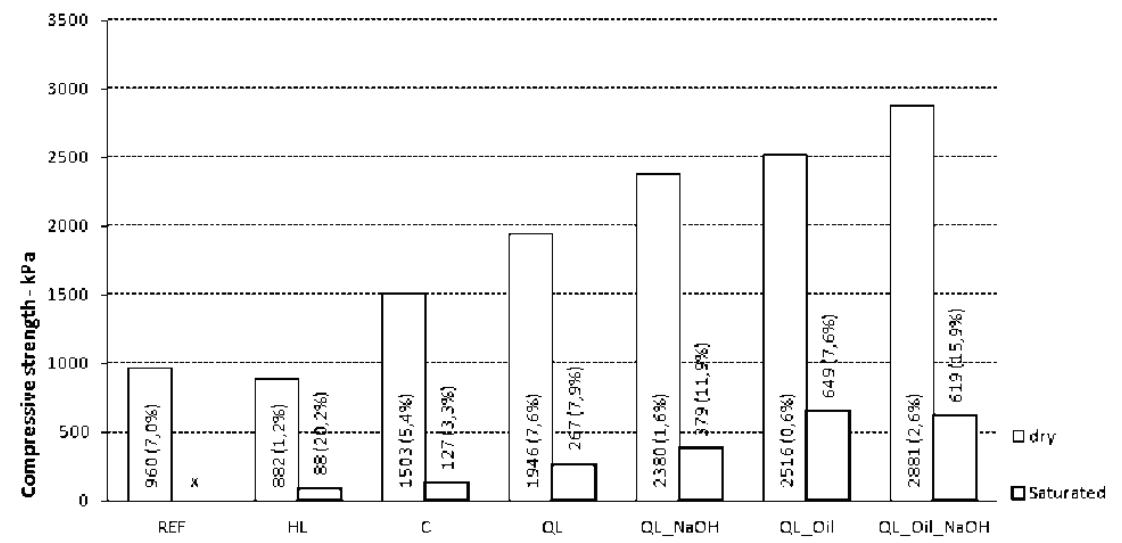

Figure 3. Compressive strength tests (dry and saturated probes) with coefficient of variation (\%)

The coefficient of absorption obtained in the water absorption by capillarity tests (Fig. 4) show that the use of quicklime reduces the absorption, above all with addition of sodium hydroxide or oil. Even the stabilization with cement or hydrated lime increases the water absorption.

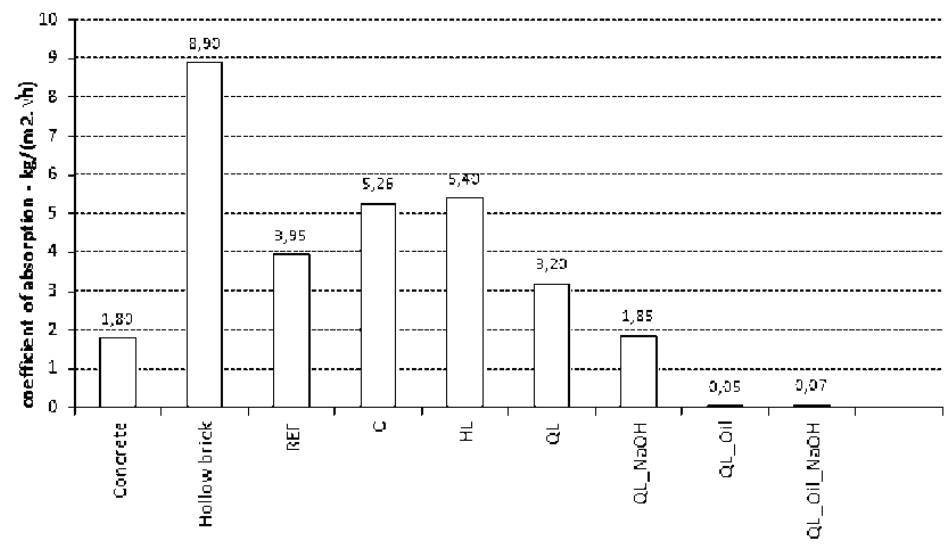

Figure 4. Coefficient of water absorption by capillarity of soil mixtures studied and common materials 
The results of water vapour permeability tests, demonstrate that the earth material has higher permeability than other common construction materials $\left(\pi=79(\mathrm{~kg} / \mathrm{m} . \mathrm{s} . P a) * 10^{12}\right)$, But the mixtures $\mathrm{C}, \mathrm{QL} \_\mathrm{NaOH}, \mathrm{QL}$ Oil and QL_Oil_NaOH have shown reduced permeability ( $\pi$ around $\left.30(\mathrm{~kg} / \mathrm{m} . \mathrm{s} . \mathrm{Pa}) * 10^{12}\right)$, but these values are higher than concrete or even the common used mortars. This way it is expectable that the addition of oil or sodium hydroxide will not compromise the necessary vapour permeability of a building for a good interior environment.

At the accelerated erosion tests, one was used the maximum value criterion of "Bulletin 5" (Middleton et al 1987) that intend for suitable resistance values lower than $1 \mathrm{~mm} /$ minute. According to this principle, the results obtained (Table 4) reveal that only the reference soil (REF) and the soil with cement $(\mathrm{C})$ exceed the limit value of erosion $(1 \mathrm{~mm} / \mathrm{min})$. The soil with hydrated lime present intermediate erosion and the mixtures with quicklime present lower values of erosion. However, there are not considerable differences among the mixtures with quicklime, with or without oil or sodium hydroxide (QL_NaOH, QL_Oil and QL_Oil_NaOH).

Table 4. Measured erosion in accelerated erosion test

\begin{tabular}{lll}
\hline Mixture & Maximum erosion $-\mathrm{mm}$ & Erosion by minute $-\mathrm{mm} / \mathrm{min}$ \\
\hline REF & 64,3 (at 2 minutes) & 32,14 \\
\hline $\mathrm{HL}$ & 25,5 & 0,27 \\
\hline $\mathrm{C}$ & 70,0 (at 15 minutes) & 1,34 \\
\hline $\mathrm{QL}$ & 5,7 & 0,08 \\
\hline QL_Oil & 11,2 & 0,19 \\
\hline QL_NaOH & 7,4 & 0,11 \\
\hline QL_Oil_NaOH & 6,6 & 0,09
\end{tabular}

\section{CONCLUSIONS}

The ancient knowledge, adequately used and well adapted to the new technologies for casting earth material, may enable innovative ways to improve the durability and the performance of earth buildings.

The use of quicklime with the mentioned hot process present in the experimental research of the authors, demonstrate a good performance, with better mechanical resistance (in dry or saturated conditions), reduced water absorption by capillarity and reduced erosion, without compromise the water vapour permeability.

The addition of oil or sodium hydroxide can improve even more this performance of quicklime. Above all, the best performance related to compressive strength was achieved adding oil with sodium hydroxide and concerning water absorption was through the addition of oil.

This way, one can conclude that these additions will be beneficial for earth construction in order to improve its durability against water action, being possible to build walls without coating it, assuring a good performance due to reduced water permeability and maintaining the high water vapor permeability of the material, one of the main advantages of earth construction.

\section{REFERENCES}

Achenza, M. \& Fenu, L. 2006. On earth stabilization with natural polymers for earth masonry construction, Materials and Structures 39:21-27, RILEM.

Anger, R., Fontaine, L. \& Houben, H., 2009. Influence de la teneur en sel et du ph sur la plasticite du materiau terre. International Conference MEDITERRA 2009, Cagliari, 13 - 16 March. Edicom Edizioni.

ASTM, D 1633 - 00, 2000. Standard Test Methods for Compressive Strength of Molded Soil-Cement Cylinders, ASTM, West Conshohocken, PA 19428-2959.

Auroville Earth Institute, Stabilised Earth Waterproofing, UNESCO Chair Earth Architecture - Representative for Asia, Auroville, India, Available at: <www.earth-auroville.com>, accessed 2008.

BASIN \& Pratical Action, 1999. Mud plasters and renders, BASIN - Building Advisory Service and Information Network.

Beas, M., 1991. Traditional architectural renders on earthen surfaces, Master Dissertation, University of 
Pennsylvania.

Browne, G., 2009. Stabilised interlocking rammed earth blocks: alternatives to cement stabilisation, Proc. Intern. Conf. 11th NOCMAT 2009, Bath, September.

Čechová, Eva, 2009. The effect of linseed oil on the properties of lime-based restoration mortars, Ph. D., University of Bologna.

CML - Câmara Municipal de Lisboa, 2005. Baixa Pombalina: bases para uma intervenção de salvaguarda, Ed. Câmara Municipal de Lisboa.

CPNT - Consejo de Promocion de Nopal y Tuna, 2009. Usos y Aplicaciones del Nopal, Available at: $<$ http://www.cpnt.org.mx $>$ [accessed 2009].

Crews, C., 2010. Earth Plasters and Aliz, in The Art of Natural Building, NetWorks' Productions, Available at: < www.networkearth.org > [accessed 2010].

Eires, R., Camões, A. \& Jalali, S., 2009. Compressed earth mixtures with metakaolin and lime additions and antifungal additives, Proc. Intern. Conf. MEDITERRA 2009, Edicom Edizioni, March.

Eires, R., Camões, A. \& Jalali S., 2010. Optimização do desempenho de construção em terra com recurso a bio-polimeros. Proc. Intern. Conf. $6^{\circ} \mathrm{ATP} / 9^{\circ}$ Siacot, Coimbra, February. Ed Argumentum.

Eires, R., 2012. Construção em Terra: Desempenho melhorado com incorporação de biopolímeros, Ph.D. University of Minho, Portugal.

Fathy, Hassan, 1969. Arquitetura para os pobres - Uma experiência no Egipto rural, original text - Cairo 1969 with the title "Gourna, a Tale of two Villages", Portugal Ed. Argumentum and Dinalivro, 2009.

Gomes, R. \& Folque, J., 1953. O uso da terra como material de construção, Technical document - C.I.T $\mathrm{N}^{\circ} 9$, serie D-4, LNEC.

Guelberth, C. \& Chiras, D., 2005. The natural plasterbook - earh lime and gypsum plasters for natural homes, New Society Publichers.

Hamer, F. \& Hamer, J., 1975. The Potter's Dictionary of Materials and Techniques, Pr. (1st Ed. 1975) 4sth Ed. 2004. Univ. of Pennsylvania.

Houben, H. \& Guillaud, H., 1989. Earth Construction - A comprehensive guide, English edition CRATerre-EAG, Practical Action Publiching, The Schumacher Centre for Technology \& Development, 2008.

Hutton, S., 2010. Answers to questions about Oman - Making sarooj, Available at: $<$ www.newsbriefsoman.info $>$ [accessed 2010].

IM, Instituto Meteorológico, 2005. Perfil Climático - Portugal Continental - Clima 1961-1990, Ed. Instituto Meteorológico, I.P., Lisbon.

IPQ, NP EN 1015-19:2000, Métodos de ensaio de argamassas para alvenaria, Parte 19: Determinação da permeabilidade ao vapor de água de argamassas de reboco endurecidas, Instituto português da qualidade, IPQ.

Kamang, E.E.J., Strength properties of compressed earth bricks (CEB) with earthworm cast as stabilizer, Journal of Environmental Sciences, 1 (2). Pp. 65-70, Faculty of Environmental Sciences, University of Jos, Nigeria, 1998.

LaBarre, Suzanne, 2010. The Better Brick: 2010 Next Generation Winner, Metropolis Magazine, Available at: <www.metropolismag.com>, accessed 2011.

Malekzadeh M.J., 2007. Dams of the Ancient City of Istakhr. Intern. History Seminar on Irrigation and Drainage, pg.121, Tehran, Maio.

Maniatidis, V. \& Walker, P., 2003. A Review of Rammed Earth Construction, DTi Partners in Innovation Project 'Developing Rammed Earth for UK Housing', May.

Martinez-Camacho, F., Vazquez-Negrete, J., Lima, Enrique, L., Victor H. \& Bosch, P., 2008. Texture of nopal treated adobe: restoring Nuestra Señora del Pilar mission, Journal of Archaeological Science $35,1125-1133$.

Middleton, G., 1987. Reviewed by Schneider, L., Bulletin 5 - Earth-Wall Construction, CSIRO-2, and 4sth edition, National Building Technology Centre, Commonwealth of Australia, Department of Industry, Technology and Commerce.

Minke, G., 2006. Building with Earth - Design and Technology of a Sustainable Architecture, Birkhäuser - Publishers for Architecture.

Minke, G., 2007, Building with earth - 30 years of research anddevelopment at the university of kassel, Proc. Intern. Conf CESB 07 PRAGUE.

Silva, B., Correia, J., Nunes, F., Tavares, P., Varum \& H., Pinto, J., 2010. Bird Nest Construction - Lessons for Building with Earth, WSEAS Transactions on Environment and Development, Issue 2, Volume 6, February.

Veiga, E., 2008. Arquitetura luso brasileira e suas relações com a toponímia, Colóquio 260 anos de herança açoriana, Florianopolis - Santa Catarina, 15 -17 September.

Vitruvius P., 2011. De architectura - Book VIII, in Vitruvius: On Architecture, Available at: $<$ http://penelope.uchicago.edu/Thayer/E/Roman/Texts/Vitruvius>, accessed 2011.

Walker, P. \& Standards Australia, 2002. HB 195-2002, The australian earth building handbook, Stand- 
ards Australia International. 